\title{
PERSONALITY ACCORDING TO THE "BIG FIVE" MODEL AND STYLES OF COPING WITH STRESS AMONG AIRCRAFT CREW MEMBERS
}

\author{
Aleksandra SZEWCZYK' , Jan F. TERELAK² \\ ${ }^{1}$ Cardinal Stefan Wyszynski University, Institute of Psychology, Warsaw, Poland \\ ${ }^{2}$ Military Institute of Aviation Medicine, Department of Flight Safety, Warsaw, Poland
}

Source of support: Own sources

Author's address: J J.F. Terelak, Military Institute of Aviation Medicine, Department of Flight Safety, Krasińskiego 54/56 Street, 01-755 Warsaw, Poland, e-mail: jterelak@wiml.waw.pl

Introduction: This is an empirical work concerning correlations between personality and style of coping with stress among pilots and board crew of commercial aircrafts.

Methods: Two groups were subjected to analysis: experimental group - pilots $(n=19)$ and board crew of commercial aircrafts $(n=22)$ and control group - merchants $(n=28)$. Styles of coping with stress were studied using Polish version of Coping Inventory for Stressful Situations (CISS) by N.S. Endler and D.A. Parker. Personality assessment was performed with the help of NEO-FFI questionnaire by P.T. Costa and R.R. McCrae based on Five Factor Theory of Personality.

Results: We demonstrated differences between pilots and board crew and control group with regard to the style of coping with stress that were determined by personality.

Discussion: Correlations between extraversion, scrupulousness, open-mindedness and preferences for task-oriented or avoiding style of coping with stress as well as neuroticism and emotional style of coping with stress were highlighted. Discussion concerns differences between experimental and control groups with regard to the choice of style of coping with stress.

Conclusions: Differences with regard to styles of coping with stress in both studied groups may result from natural professional preselection of aircraft staff.

Keywords: pilots, aircraft personnel, coping with stress, "big-five" theory of personality

Tables: 3 • References: 19 • Full-text PDF: http://www.pjamp.com • Copyright @ 2013 Polish Aviation Medicine Society, ul. Krasińskiego 54/56, 01-755 Warsaw, license WIML •Indexation: Index Copernicus, Polish Ministry of Science and Higher Education 


\section{INTRODUCTION}

Personality differentiates people with regard to, among other things, subjective perception of both positive and negative emotion. Therefore, we decided to examine the association between independent variable, such as personality, and styles of coping with stress. In the context of presented variables it is also important to choose an experimental group. Members of aircraft crew work under stress-generating conditions [18].

During the last decade literature on the topic emphasizes the Five Factor Theory of Personality by P.T. Costa and R.R. McCrae [2] belonging to the previously valid factorial theories of personality by R.B. Cattell or H.J. Eysenck designed to rationalize the taxonomy of individual differences with regard to demonstrating coherent behaviors, emotions and feelings [2]. None of available publications by Costa and McCrae contains a clearly formulated definition of personality. Authors of this model define personality operationally, referring to it as "(...) a structure of most basic dimensions that influence characteristics identifiable in both natural languages as well as in psychological questionnaires (...)" [2]. Therefore, these characteristics are rather predispositions, since tendencies themselves do not determine behavior, which is influenced by a number of other conditions.

Results of analysis of the so-called free personality descriptions and 16-PF by Cattell, which led to development of three-factor personality structure encompassing: neuroticism, extraversion and openness (to experience), were concordant with this theory. The remaining two dimensions contained in the final version of five-factor theory: agreeableness and conscientiousness were included in the model due to lexical studies. The distinguished five factors are determined biologically, as it is in case of temperament [11]. Another aspect of five-factor theory is its causative nature. Costa and McCrae [3] created a list consisting of six postulates for their theory: (1) Basic tendencies: individuality, endogenous origin, permanent development, hierarchical structure; (2) Characteristic adaptations: adaptation through learned patterns, maladaptation, plasticity; (3) Objective biography: multiple determination, course of life; (4) Self-image consisting of elements: self-schema and selective perception; (5) External influences and its components: interaction between social and physical environment, apperception, reciprocity; (6) Dynamic processes: universal dynamics and discriminating dynamics.

Critics of this theory, including D. Cervone and L.A. Pervin [1] claim that, even though the model has great integrative potential (it combines bio- logical approach to characteristics and environmental influence with observable personality variables), it lacks specified sets of biological and psychological mechanisms that relate to personality and explain the influence of external environment on personality structure.

Problem of coping with stress is a derivative of Transactional Model of Stress by R. Lazarus and S. Folkman [10], who introduced to psychology of stress the mechanism explaining development of stress transaction resulting from cognitive assessment as judged by the stressor (primary assessment) in relation to one's own preventative capabilities (secondary assessment). N.S. Endler and J.D.A. Parker [6], who formulated the concepts of styles of coping with stress by dividing them according to criteria: confrontation and focus on oneself, refer to this model. This way, they defined three styles: confrontational, person-oriented; avoidant, task-oriented; avoidant, emotion-oriented, building a tool for studying them known in the literature as Coping Inventory for Stressful Situations - CISS [5]. Literature data on the topic yield study results indicating a correlation between personality and preference for a particular style of coping with stress $[8,14]$.

\section{Hypotheses:}

The fundamental goal of this work is to examine association between personality and styles of coping with stress. Theoretical concepts described above create a foundation for expectations that there could be a connection between personality and style of coping with stress among aircraft crew, who are exposed to specific flight conditions during work, which generate severe stress [18].

Hypothesis 1. There is a relationship between personality and preferred style of coping with stress.

1a. There is a positive correlation between neuroticism and style of coping with stress concentrated on emotion, as high degree of neuroticism indicates susceptibility to negative emotion, tendency for hypochondria and emotionality, as well as concentration on one's own emotional experiences [9].

$1 \mathrm{~b}$. There is a positive correlation between extraversion and task-oriented style of coping among aircraft crew, as extraverted persons are characterized by openness, sociability, activity and exhibit tendencies toward positive thinking, which enables them to concentrate on solving the problem under stressful conditions [7].

$1 c$. There is a positive correlation between scru- 
pulousness and task-oriented style of coping among aircraft crew, as aircraft personnel is subjected to multi-stage recruitment that selects for this personality feature [16].

Hypothesis 2. There is a difference between aircraft crew and control group with regard to the styles of coping with stress, as according to literature data, aircraft personnel exhibits a tendency toward task-oriented style of coping.

\section{METHODS}

\section{Study group characteristics}

In the discussed report study groups included pilots and board crew of charter airline. Control group encompassed shopping center employees. The study included 19 pilots and 22 members of board crew. Age of pilots ranged 27-63 years, while that of board crew 21-31 years. Control group consisted of 28 stationary airport employees aged 20-57 years. Both aircraft crew and members of the control group presented with secondary and higher education level.

\section{Study methods}

- Personality evaluation was performed using NEO-FFI questionnaire by P.T. Costa and R.R. McCrae (2005) based on a Five Factor Model of Personality (so-called Big Five Model). Description of personality is formed based on five scales measuring: neuroticism $(\mathrm{N})$, extraversion $(\mathrm{E})$, openness $(\mathrm{O})$, agreeableness $(\mathrm{A})$ and conscientiousness (C). Polish version contains good psychometric characteristics [19].

- Styles of coping with stress among studied subjects were verified using a Coping Inventory for Stressful Situations (CISS) tool created by [5]. Polish version of the questionnaire was created by [13].
Theoretical basis refer to the transactional model of stress proposed by [10]. Results are shown on three scales: task-oriented style (TO), emotionoriented style (EO) and avoidance-oriented (AO) style. The last one may take two forms: engaging in substitute activities (SA) or seeking social contacts (SC). The tool possesses good psychometric properties.

\section{RESULTS}

Statistical analysis was conducted using IBM SPSS 21 software. Results of Shapiro-Wilk test for normal distribution for studied variables in compared groups are presented in Table 1.

As shown by Table 1, close to normal distributions were obtained in both groups for all scales of NEO-FFI questionnaire, as well as for the CISS questionnaire scales and SA subscale. Distribution of SC subscale in the control group.

In order to verify the hypothesis regarding correlation between personality features and styles of coping with stress we used Pearson's $r$ coefficient. Correlation between personality and style of coping with stress among aircraft crew is presented in Table 2.

Analysis of results presented in Table 2 shows many significant correlations between personality features and preferred style of coping with stress in the experimental group. Extraversion correlates positively with task-oriented style of coping, which corroborates the assumed hypothesis, as well as avoidance-oriented style and both of its subscales. All of these correlations are positive and moderate.

Neuroticism correlates positively with emotion-oriented style, avoidance-oriented style and SA (substitute activities) subscale. The latter two

Tab. 1. Results of Shapiro-Wilk test for normal distribution for studied variables in compared groups.

\begin{tabular}{|c|c|c|c|c|c|c|}
\hline \multirow{2}{*}{ Scale } & \multicolumn{3}{|c|}{ Study group } & \multicolumn{3}{|c|}{ Control group } \\
\hline & w & df & $\mathbf{p}$ & w & df & $\mathbf{p}$ \\
\hline Extraversion & 0.979 & 41 & 0.648 & 0.930 & 28 & 0.062 \\
\hline Neuroticism & 0.966 & 41 & 0.248 & 0.971 & 28 & 0.602 \\
\hline Openness to experience & 0,980 & 41 & 0.678 & 0.930 & 28 & 0.060 \\
\hline Agreeableness & 0.983 & 41 & 0.796 & 0.949 & 28 & 0.189 \\
\hline Conscientiousness & 0.957 & 41 & 0.119 & 0.972 & 28 & 0.625 \\
\hline то & 0.963 & 41 & 0.193 & 0.936 & 28 & 0.086 \\
\hline EO & 0.987 & 41 & 0.903 & 0.946 & 28 & 0.156 \\
\hline AO & 0.955 & 41 & 0.102 & 0.938 & 28 & 0.099 \\
\hline SA & 0.961 & 41 & 0.175 & 0.955 & 28 & 0.262 \\
\hline SC & 0.977 & 41 & 0.560 & 0.925 & 28 & 0.046 \\
\hline
\end{tabular}


Tab. 2. Pearson's $r$ coefficients for NEO-FIT and CISS scales in the study group.

\begin{tabular}{|c|c|c|c|c|c|c|}
\hline & & TO & EO & AO & SA & sc \\
\hline \multirow{2}{*}{ Extraversion } & $r$ & $0.358^{*}$ & -0.009 & $0.495^{* *}$ & $0.429^{* *}$ & $0.483^{* *}$ \\
\hline & $\mathrm{p}$ & 0.021 & 0.955 & 0.001 & 0.005 & 0.001 \\
\hline \multirow{2}{*}{ Neuroticism } & $r$ & -0.235 & $0.720^{* *}$ & $0.454^{* *}$ & $0.586^{* *}$ & 0.131 \\
\hline & $\mathrm{p}$ & 0.139 & 0.000 & 0.003 & 0.000 & 0.415 \\
\hline \multirow{2}{*}{ Openness } & $r$ & 0.135 & 0.248 & $0.544^{* *}$ & $0.585^{* *}$ & $0.311^{*}$ \\
\hline & $\mathrm{p}$ & 0.401 & 0.117 & 0.000 & 0.000 & 0.048 \\
\hline \multirow{2}{*}{ Agreeableness } & $r$ & -0.088 & -0.308 & -0.161 & $-0.323^{*}$ & 0.150 \\
\hline & $\mathrm{p}$ & 0.584 & 0.050 & 0.314 & 0.039 & 0.350 \\
\hline \multirow{2}{*}{ Conscientiousness } & $r$ & $0.369^{*}$ & $-0.456^{* *}$ & $-0.345^{*}$ & $-0.436 * *$ & -0.192 \\
\hline & $\mathrm{p}$ & 0.018 & 0.003 & 0.027 & 0.004 & 0.228 \\
\hline
\end{tabular}

*Significant correlation for value of $0.05 ; *$ Significant correlation for value of 0.01

correlations are moderate, while the correlation with EO scale is strong ( $r>0.7)$ and supports our hypothesis.

The hypothesis of positive correlation between conscientiousness and task-oriented style of coping with stress was also confirmed. Conscientiousness was also negatively correlated with $\mathrm{EO}$ an $\mathrm{AO}$ scales as well as SA subscale (all correlations were moderate).

With regard to openness to experience we obtained moderately positive correlations with avoidance-oriented style and its two subscales: SA and SC. Agreeableness moderately correlated negatively with $\mathrm{SA}$ subscale.

Another studied problem involved inter-group differences, which were assessed using student's $\mathrm{t}$-test for all scales and SA subscale and U MannWhitney test for SC subscale, as its distribution was far from normal in the control group. Before performing a t-test we used Levine's test to check for homogeneity of variance. In case of TO and EO scales variances appeared to be heterogeneous. Results of tests for significance of differences are presented in Table 3.
We confirmed a hypothesis regarding stronger tendency for task-oriented coping with stress among members of aircraft crew compared to control group (t $(44.97)=2.272 ; \mathrm{p}<0.05)$. The experimental group assumed this style significantly more often $(M=65.12 ; S D=6.71)$ than control group $(M=60.39 ; S D=9.52)$. In order to assess the magnitude of obtained effect Cohen's d coefficient was calculated. Its value indicates moderate difference between groups $(\mathrm{d}=0.68)$.

Moreover, there was a significant difference between experimental and control group with regard to the tendency toward assuming emotion-oriented style ( $t(67)=-4.047 ; p<0.01)$. Control group received higher scores in $\mathrm{EO}$ scale $(\mathrm{M}=45.79$; $S D=7.62)$ than aircraft personnel group $(M=36.76$; $\mathrm{SD}=9.98)$. Magnitude of Cohen's d coefficient $(d=0.99)$ indicates great strength of the obtained effect.

Differences in results acquired in $\mathrm{AO}$ scale between compared groups were not statistically significant.

Tab. 3. Differences in CISS questionnaire scores between study group and control group.

\begin{tabular}{|c|c|c|c|c|c|c|c|}
\hline Scale & Group & $\mathbf{n}$ & Mean & $\begin{array}{l}\text { Standard } \\
\text { deviation }\end{array}$ & $t / z$ & df & p \\
\hline \multirow{2}{*}{ TO } & Study & 41 & 65.12 & 6.71 & \multirow{2}{*}{2.272} & \multirow{2}{*}{44.97} & \multirow{2}{*}{0.028} \\
\hline & Control & 28 & 60.39 & 9.52 & & & \\
\hline \multirow{2}{*}{ EO } & Study & 41 & 36.76 & 9.98 & \multirow{2}{*}{-4.047} & \multirow{2}{*}{67} & \multirow{2}{*}{0.000} \\
\hline & Control & 28 & 45.79 & 7.62 & & & \\
\hline \multirow{2}{*}{$\mathrm{AO}$} & Study & 41 & 42.93 & 11.99 & \multirow{2}{*}{-1.606} & \multirow{2}{*}{66.97} & \multirow{2}{*}{0.113} \\
\hline & Control & 28 & 46.86 & 8.33 & & & \\
\hline \multirow{2}{*}{ SA } & Study & 41 & 18.12 & 6.81 & \multirow{2}{*}{-1.208} & \multirow{2}{*}{67} & \multirow{2}{*}{0.231} \\
\hline & Control & 28 & 20.07 & 6.23 & & & \\
\hline \multirow{2}{*}{ SC } & Study & 41 & 16.78 & 4.42 & \multirow{2}{*}{-0.938} & & \multirow{2}{*}{0.348} \\
\hline & Control & 28 & 17.57 & 3.47 & & & \\
\hline
\end{tabular}




\section{DISCUSSION}

One of the goals of this study was to examine the association between personality and preferred style of coping with stress among aircraft crewmembers. In concordance with our expectations, study demonstrated a correlation between neuroticism and style of coping concentrated on emotion. We showed a positive correlation between the above variables thus, aircraft crewmembers exhibiting neurotic behaviors prefer a style of coping with stress concentrated on emotion. Correlation between extraversion and task-oriented style of coping was confirmed, as we showed a positive correlation, as well as between extraversion and style concentrated on avoidance, including its two subscales. Members of aircraft crew who obtained high scores on the Extraversion scale prefer task-oriented style and avoidance-oriented style. Hypothesis of positive correlation between conscientiousness and style of coping with stress concentrated on a task was also confirmed, which means that aircraft crewmembers who acquired high scores in Conscientiousness scale exhibit a tendency to present task-oriented style. Moreover, conscientiousness demonstrated negative correlation with emotionoriented style and avoidance-oriented style, as well as engagement in substitute activities scale. Openness to experience, however, correlates positively with avoidance-oriented style and both of its subscales: engagement in substitute activities and seeking social contact. Presented results are consistent. Acquired data allow to conclude that aircrew staff who exhibit extraverted (are open, active, eager to act) and conscientious behaviors (are scrupulous and reliable) prefer a style of coping with stress concentrated on the task and avoidance, including its two subscales. These subscales, although characterizing avoidant approach toward the existing problem, they constitute a type of activity often assumed by extraverted persons. People characterized by neuroticism prefer emotion-concentrated style, avoidance-oriented style and engaging in substitute activities aimed at evading the actual problem. Specific nature of the study group should be emphasized. We found that aircraft crewmembers for the most part recruit from highly extraverted (60.98\%) persons and are characterized by low level of neuroticism (60.98\%). None of the subjects from experimental group achieved high scores in Neuroticism scale. Among other things, this data emphasizes the meaning of conducting a multi-stage process of recruitment for aircrew board staff, during which candidates are tested for various behaviors and reactions with regard to resistance to stress.

Studies examining the relationship between strategies and styles of coping with stress and personality distinguish two approaches. The first approach includes studies, in which coping with stress (situational) correlates with a single characteristic or a group of characteristics on the ground of a given theory or on empirical basis. The second approach involves taking personality structure into consideration. In our study we are in agreement with this second approach, in which personality structure of aircraft staff differs significantly from personality structure presented by the control group, exhibiting greater tendency for self-guidance as well as sense of responsibility for performed duties and proper relations with passengers present on board. It is in agreement with literature data on the topic [17]. It is also corroborated by identified differences between experimental and control group with regard to preferred task-oriented style of coping with stress, which has been previously demonstrated on a group of stewardesses and waitresses unrelated to aviation [15].

Work on board of an aircraft requires quick reaction to rapidly changing flight conditions, unexpected situations and conforming to passengers' attitudes. Under such circumstances, concentration on a task is a fundamental criterion of choice for aircraft staff [4]. Ability to solve problems against pressure is one of the features enabling suitable crew cooperation, which determines flight safety [12].

\section{CONCLUSIONS}

With regard to the results of conducted study, we may identify significant correlations between:

1) neuroticism and emotion-oriented style of coping with stress,

2) extraversion and task-oriented style of coping with stress,

3) extraversion and avoidance-oriented style of coping with stress,

4) conscientiousness and task-oriented style of coping with stress,

5) openness to experiences and style of coping with stress concentrated on avoidance.

Moreover, we found differences between aircraft crew and control group with respect to preferred styles of coping with stress. 
Original Article

\section{AUTHORS' DECLARATION:}

Study Design: Aleksandra Szewczyk, Jan F. Terelak; Data Collection: Aleksandra Szewczyk, Jan F. Terelak; Statistical Analysis: Aleksandra Szewczyk; Manuscript Preparation: Jan F. Terelak; Funds Collection: Aleksandra Szewczyk, Jan F. Terelak. The Authors declare that there is no conflict of interest.

\section{REFERENCES}

1. Cervone, D., Pervin, L.A. (2011) Osobowość. Teoria i badania. Kraków: Wydawnictwo Uniwersytetu Jagiellońskiego.

2. Costa, P.T., Mc Crae, R.R. (1992) Four ways five factors are basic. Personality and Individual Differences. 13 (6). $653-665$.

3. Costa, P.T., Mc Crae, R.R. (2005) Osobowość dorosłego człowieka. Perspektywa teorii pięcioczynnikowej (p. 13-53). Kraków: Wydawnictwo WAM.

4. Damos, D.L., John, R.S., Lyall, E.A. (2005) Pilot Activities and the Level of Cockpit Automation. The International Journal of Aviation Psychology. 15(3). 251-268.

5. Endler, N. S., Parker, J.D.A. (1990) Coping Inventory for Stressful Situations (CISS): Manual. Toronto: Multi-Health Systems, Inc.

6. Endler, N.S., Parker, J.D.A., (1994) Assessment of multidimensional coping: task, emotion and avoidance strategies. Psychological Assessment. 6 (1). 50-60.

7. Gasiul, H. (2012) Psychologia osobowości. Nurty, koncepcje, teorie. Warszawa: Wydawnictwo Engram.

8. Heszen-Niejodek, I. (2000) Stres i radzenie sobie- główne kontrowersje (p.16-27). In: Heszen-Niejodek, I., Ratajczak, Z. (eds.): Człowiek w sytuacji stresu. Problemy teoretyczne i metodologiczne. Katowice: Wydawnictwo Uniwersytetu Śląskiego.

9. Jaworowska, A., Strelau, J., Szczepaniak, P., Wrześniewski, K. (2005) Kwestionariusz Radzenia Sobie w Sytuacjach Stresowych CISS. Warszawa: PTP.

10. Lazarus, R.S., Folkman, S., (1984) The stress and coping paradigm. New York: Springer.

11. Mc Crae, R.R., John, O.P. (1992) An introduction in the Five-Factor Model and its applications. Journal of Personality. 60 (2). 175-215.

12. Siegoczyńska, N., Terelak, J.F. (2007) Poczucie koherencji a radzenie sobie ze stresem u personelu pokładowego PLL LOT. Polski Przegląd Medycyny Lotniczej. 13 (1). 9-23.

13. Szczepaniak, P., Strelau, J., Wrześniewski, K. (1996) Diagnoza stylów radzenia sobie ze stresem za pomocą polskiej wersji kwestionariusza CISS Endler i Parker. Przegląd Psychologiczny. 39 (1-2). 2-39.

14. Terelak, J.F. (ed.). (1997) Studia z psychologii stresu. Radzenie sobie ze stresem. Uwarunkowania i strategie. Warszawa: Wydawnictwa ATK.

15. Terelak, J.F., Braun, M. (2001) Umiejscowienie poczucia kontroli wzmocnień a style radzenia sobie ze stresem u stewardess. Polski Przegląd Medycyny Lotniczej. 7 (4). 329-342.

16. Terelak, J.F., Braun, M., Renowicka, J. (2007) Stewardesy (stewardzi). In: Terelak, J.F. (ed.): Stres zawodowy: Charakterystyka psychologiczna wybranych zawodów stresowych. Warszawa: Wyd. UKSW. 426-446.

17. Terelak, J.F., Stefańczyk, A. (2010) Osobowość według “Wielkiej Piątki” a style radzenia sobie ze stresem u kontrolerów ruchu lotniczego. Polski Przegląd Medycyny Lotnicze 16 (2). 131-141.

18. Terelak, J.F., Kobos, Z., Truszczyński, O., Tarnowski, A., Maciejczyk, J. (2007) Piloci. In: Terelak, J.F. (ed.). Stres zawodowy: Charakterystyka psychologiczna wybranych zawodów stresowych. Warszawa: Wyd. UKSW. (333-382).

19. Zawadzki, B., Szczepaniak, P. Strelau, J. (1995) Diagnoza psychometryczna pięciu wielkich czynników osobowości: Adaptacja kwestionariusza NEO-FFI Costa i Mc Crae do warunków polskich. Studia Psychologiczne. 33. 189-225.

Cite this article as: Szewczyk A, Terelak J F: Personality according to the "Big Five" model and styles of coping with stress among aircraft crew. Pol J Aviat Med Psychol, 2013; 19(2): 5-10. 